This is the post-print version of an article published in Journal of Cleaner Production. Please cite this article as follows:

Lambrechts, W., Mulà, I., Ceulemans, K., Molderez, I. and Gaeremynck, V. (2013). The integration of competences for sustainable development in higher education: an analysis of bachelor programs in management, Journal of Cleaner Production, 48, pp. 65-73.

To link to this article: http://dx.doi.org/10.1016/j.jclepro.2011.12.034

\title{
The integration of competences for sustainable development in higher education: an empirical analysis of bachelor programs in management.
}

\author{
Wim Lambrechts ${ }^{13^{*}}$ \\ Ingrid Mulà ${ }^{2}$ \\ Kim Ceulemans ${ }^{1}$ \\ Ingrid Molderez ${ }^{1}$ \\ Veerle Gaeremynck ${ }^{3}$ \\ ${ }^{1}$ Hogeschool-Universiteit Brussel, Warmoesberg 26, B-1000 Brussels, Belgium \\ 2 RCE Severn, University of Gloucestershire, Oxstalls Campus, GL50 2RH, Gloucester, \\ GL2 9HW, United Kingdom \\ ${ }^{3}$ Leuven University College, Abdij van Park 9, B-3001 Leuven, Belgium
}

${ }^{*}$ Corresponding author. Wim Lambrechts is holder of a Special PhD Fellowship of the Research Foundation - Flanders (FWO). E-mail address: wim@lambrechts.org, website: www.sustainablehighereducation.com 


\begin{abstract}
Over the past years, many universities have integrated sustainability into their education, research, outreach, and operations. Within education, competences regarding sustainable development (SD) have been defined, courses on sustainability have been developed, and manuals and methods for teaching SD have been developed and integrated in curricula. The integration of competences for SD in higher education programs can be seen as an important step in achieving sustainability in higher education. Although these competences are defined and described in different models and settings, little information is available on the actual status of the integration of competences for SD in different study programs. In order to find out how and to what extent these competences are already present, the existing competence schemes of study programs within two Belgian universities were analyzed in the fields of business management, office management, and applied information technology. Results of the analysis show that competences for SD related to responsibility and emotional intelligence are widely integrated, while competences for SD dealing with system orientation, future orientation, personal commitment, and action taking are virtually absent. The analysis also shows that many competences for SD could be discovered within the selected study programs, though in an implicit and fragmented way, thus not covering all necessary fields of knowledge, skills, and attitudes. This calls for an adjustment of the study programs to clearly and explicitly integrate competences for SD, especially those related to system orientation, future orientation, personal involvement, and action taking.
\end{abstract}

\title{
Keywords
}

Sustainability in higher education; competences; education for sustainable development, sustainability integration assessment.

\section{Introduction}

The appeal for education to contribute to a sustainable society is an important new challenge and characteristic for twenty-first century higher education. The UN Decade of Education for Sustainable Development (DESD), in its last phase (2005-2014), calls for a thorough integration of sustainability issues at all levels of education via a holistic, inter- and transdisciplinary approach and with a clear focus on values (UNESCO, 2009). Another emerging field of interest within higher education, often leading to extended debate, is competence-based education. Competences integrate knowledge, skills, values and 
attitudes (Rychen and Salganik, 2003, Baethge et al. 2006). Competence-based education is a type of education that focuses on the clear definition of competences to be achieved and assessed during the education program. Although both educational innovations have their merits for universities - as will be further addressed in section 2 and 3 - they also seem to guide higher education in opposite directions. This is due to the fact that integrating competences seems to transform the education programs radically, in order to be able to assess and "measure" each (sub-)competence, thereby negatively affecting the values that were (are) inherent to education, exactly because values are very hard to measure (Cheetham and Chivers, 1996, Hermans, 2007). On the other hand, education for sustainable development (ESD) tries to incorporate competences for sustainable development (SD), linked with responsibility, emotional intelligence, system orientation, future orientation, personal involvement, and action taking (De Haan, 2006, Sleurs, 2008, Roorda, 2010). As these competences for SD are fundamentally based on values and ethics (UNESCO, 2009), their integration into higher education seems to be contradictory with competence-based education programs.

This article focuses on how these two, seemingly opposing, educational innovations can be combined to strengthen the integration of SD in higher education. Throughout the years, different competences for SD were defined in different settings (De Haan, 2006, Sleurs, 2008, Roorda, 2010), offering a complete set of knowledge, skills, values, and attitudes necessary to ensure today's students and future leaders are ready to deal with complex issues regarding sustainability, and achieve a sustainable future (Cortese, 2003, Lambrechts et al., 2009). Although these sets of competences for SD - addressed in section 3, Table 1 are highly valuable, information about the current status of the integration of these competences for SD in different study programs is required in order to introduce new competences into study programs or reorient existing competences within the framework of sustainability.

In order to find out how and to what extent sustainability-related competences are already integrated in the existing competence schemes of different study programs, the competences within two Belgian universities were analyzed in the fields of business management, office management, and applied information technology. This approach gives a concrete starting point to further integrate competences for SD into study programs, reorient existing competences towards sustainability, and to a wider extent, rebuild the curriculum towards SD. 


\section{Higher Education and Sustainability}

The opportunities and challenges inherent to SD have been outlined in numerous international declarations. In 1992, the Rio Summit (UNCED 1992) played a key role in creating momentum and global engagement to the sustainability agenda. It recognized the needs for enhancing quality of life across the globe through social justice, responsible economic development, and environmental protection. Ten years later, at the last UN World Summit on Sustainable Development (UN 2002) in Johannesburg 2002, world leaders acknowledged the urgency with which they must address this challenge, as no country was close to achieving sustainability. One year from the next Earth Summit which will be held in Rio de Janeiro (June 4-6, 2012), the pathways towards SD are still unclear and yet to be agreed upon.

Moving towards SD requires new mental models which can transform the way we interpret and respond to our existing world (Tilbury and Mulà, 2011). The UN DESD points to education and learning as core activities to facilitate critical processes which can challenge mindsets and actions in the area of sustainability. UNESCO, the official international lead agency for the DESD, encourages stakeholders, policy-makers, major groups, and institutions to embed SD into all learning spheres (UNESCO, 2005). Higher education institutions are key players in this critical process as they prepare the future generations of decision-makers, policy-makers, and business leaders (Cortese, 2003).

The involvement of higher education institutions in embedding sustainability is reflected in the numerous charters and declarations signed by university leaders, such as the Talloires Declaration (1990), the Halifax Declaration (1992), the Swansea Declaration (1993), Copernicus Charter (1994), the Declaration of Thessaloniki (1997), and the Lüneburg Declaration (2001). Through all these declarations, universities around the globe have committed to redefine and reorient their teaching and learning, research activities, and management. In other words, they have committed to become real catalysts for change towards sustainability (Wright, 2004, Lozano et al., 2010).

Over the past years, in order to accomplish this commitment, much has been achieved in education, research, outreach, operations, and reporting at the university level. Many universities have implemented innovative campus management projects which are intended to reduce their ecological footprint (e.g. Savely et al., 2007, Viebahn, 2002, Müller, 2005, Barnes and Jerman, 2002, Shriberg, 2002a). Research at the university level has contributed to the advancement of knowledge in the areas of sustainability and 
environmental systems, such as climate change (e.g. Calder and Clugston, 2003, Fien, 2002). Regarding teaching and learning, specialist courses and minors in SD or interdisciplinary courses have been created and integrated in the curriculum (e.g. Junyent and Geli, 2007, Sleurs, 2008), new pedagogical and methodological approaches have been tested and described (e.g. Ceulemans and De Prins, 2010, Lidgren et al., 2005, Steiner and Posch, 2006, Sterling, 2004, Scoullos and Malotidi, 2004), and competences have been defined and interpreted within the framework of sustainability (Barth et al., 2007, De Haan et al., 2006, Sleurs, 2008, Roorda, 2010). In order to assess and report their efforts, indicators and assessment tools were designed and tested (e.g. Shriberg, 2002b, Roorda, 2002, Behrens and Müller-Christ, 2005, Lozano, 2006a, Lozano, 2011, Ceulemans, De Prins, Cappuyns and De Coninck, 2011).

Despite all these advances, higher education institutions are far from reorienting themselves towards sustainability (Sterling and Scott, 2008, Sterling, 2004, Wals and Jickling, 2002). If we look carefully at the core business and activity of a higher education institution-i.e., teaching and learning -we observe that sustainability has been integrated into the curriculum in peace-meal, rather than holistic approaches. Different barriers for this paradigm shift can be defined at different levels (Lozano, 2006b, Velázquez et al. 2006, Lambrechts et al. 2009, Lozano, 2010, Ceulemans et al., 2011), but when it comes to education, the rigid disciplinary structures of universities and content-based learning are acknowledged to be key barriers in embedding sustainability in an integrative way (Wals 2010). The formal curriculum is more centered in the transmission of knowledge, rather than in the facilitation of critical, innovative, and creative learning spaces where students can challenge their own models of thinking and practice, develop their own innovative and creative projects, or explore alternative ideas and choices (Corcoran and Wals, 2004). In other words, until now, teaching and learning in higher education has provided few opportunities for students to develop their own values, skills, and attitudes to become change agents in the area of sustainability.

\section{Competences for Sustainable Development}

Different definitions and interpretations of competences or competence-based education can be found in the literature. Many times, the use of competences has been misunderstood or interchanged by knowledge, skills, values, or attitudes (Baethge et al., 2006). It is acknowledged that competences embrace much more than knowledge and skills. Rychen and Salganik (2003, p. 43) define competences as, "the ability to successfully meet complex demands in a particular context through the mobilization of psychological prerequisites (including both cognitive and non-cognitive aspects)." Furthermore, the term "key 
competence" refers to those competences relevant and useful for everybody and in different contexts. Key competences can be seen as relevant competences used to deal with the multiple challenges with which modern societies are now facing, such as globalization, modernization, social cohesion, or sustainable development (Barth et al., 2007, Rychen and Salganik, 2003).

Competence-based higher education enables students to gain important knowledge, skills, values, and attitudes, which they will require in their future professional and personal lives. Rychen (2002) affirms that the use of competences contributes to improving the process of assessing students, regarding the abilities they acquire to face life's challenges, but also to setting key educational goals which improve education systems and lifelong learning processes. Although the advantages are clear, the concept and process of defining competences has to be perceived with caution. Several authors point out that, within the context of professional bachelor programs, the conversion to competence-based education seems to cause a suppression of values that were (are) inherent to education (Cheetham and Chivers, 1996, Hermans, 2007). This has problematic consequences for the integration of (education for) sustainable development, since this concept is based upon values, attitudes, and ethics (Muijen, 2004). One may conclude that, if not approached carefully, the introduction of competences could be contradictory with values and, to a wider extent, the concept of SD.

Introducing key competences for SD can be seen as an important step in the integration of sustainability in higher education. Several authors report on these competences, using different settings and models (e.g. De Haan, 2006, Sleurs, 2008, Roorda, 2010), however with similar characteristics: responsibility (values, ethics, reflection), emotional intelligence (transcultural understanding, empathy, solidarity, compassion), system orientation (interdisciplinary), future orientation, personal involvement (self-motivation, motivating others, learning), and the ability to take action (participatory skills). Table 1 gives an overview of the competences for SD, as defined by De Haan (2006) and Sleurs (2008), and illustrates the way in which those competences match with the competences defined by Roorda (2010). A detailed overview of the competences as defined by Roorda (2010) is given in Table 3. 
Table 1. Competences of education for sustainable development

\begin{tabular}{|c|c|c|c|c|c|c|c|}
\hline & Roorda (2010) & 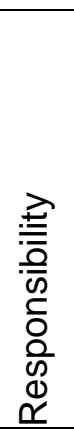 & 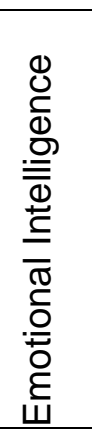 & 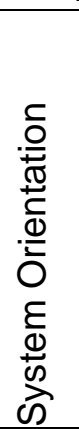 & 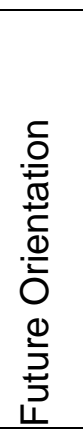 & 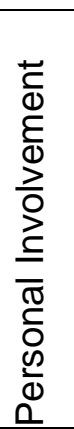 & 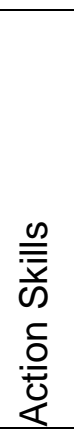 \\
\hline \multirow{8}{*}{$\begin{array}{l}\text { De Haan } \\
\text { (2006) }\end{array}$} & Competence in foresighted thinking; & & & & $\checkmark$ & & \\
\hline & Competence in interdisciplinary work; & & & $\checkmark$ & & & \\
\hline & $\begin{array}{l}\text { Competence in cosmopolitan perception, } \\
\text { transcultural understanding and } \\
\text { cooperation; }\end{array}$ & & $\checkmark$ & & & & \\
\hline & Learning participatory skills; & & & & & & $\checkmark$ \\
\hline & $\begin{array}{l}\text { Competence in planning and } \\
\text { implementation skills; }\end{array}$ & & & & & & $\checkmark$ \\
\hline & $\begin{array}{l}\text { The capacity for empathy, compassion } \\
\text { and solidarity; }\end{array}$ & & $\checkmark$ & & & & \\
\hline & $\begin{array}{l}\text { Competence in self-motivation and } \\
\text { motivating others; }\end{array}$ & & & & & $\checkmark$ & $\checkmark$ \\
\hline & $\begin{array}{l}\text { Competence in distanced reflection on } \\
\text { individual and cultural models. }\end{array}$ & $\checkmark$ & $\checkmark$ & & & & \\
\hline \multirow{5}{*}{$\begin{array}{l}\text { Sleurs } \\
(2008)\end{array}$} & Values and ethics; & & $\checkmark$ & & & & \\
\hline & Emotions; & & $\checkmark$ & & & & \\
\hline & System thinking; & & & $\checkmark$ & & & \\
\hline & Knowledge; & $\checkmark$ & & & & $\checkmark$ & \\
\hline & Action. & & & & & & $\checkmark$ \\
\hline
\end{tabular}

Research in different bachelor programs in the fields of business management, teacher training, social work, health care, and technology point out that study programs have different approaches for integrating competences of SD: horizontal, vertical, or combined (Lambrechts et al. 2010). Table 2 gives a detailed overview of these integration strategies, including their strengths and weaknesses. 
Table 2. Integration strategies for competences for sustainable development (Lambrechts et al. 2010)

\begin{tabular}{|c|c|c|c|c|}
\hline Strategy & Description & Strength & Weakness & Applied in \\
\hline $\begin{array}{l}\text { Vertical } \\
\text { Integration }\end{array}$ & $\begin{array}{l}\text { Elements of } \\
\text { Sustainable } \\
\text { Development } \\
\text { (SD) are } \\
\text { mentioned in } \\
\text { one } \\
\text { competence } \\
\text { which is } \\
\text { explicitly } \\
\text { focused on } \\
\text { sustainability. }\end{array}$ & $\begin{array}{l}\text { SD is explicitly } \\
\text { mentioned in } \\
\text { the competence } \\
\text { matrix, thus } \\
\text { encouraging } \\
\text { integration in } \\
\text { the curriculum. }\end{array}$ & $\begin{array}{l}\text { SD is } \\
\text { considered an } \\
\text { "extra" topic, } \\
\text { added to the } \\
\text { matrix and } \\
\text { clearly } \\
\text { separated from } \\
\text { other } \\
\text { competences. }\end{array}$ & $\begin{array}{l}\text { Economical } \\
\text { bachelor } \\
\text { programs } \\
\text { (finance, } \\
\text { accounting, } \\
\text { marketing), } \\
\text { office } \\
\text { management. }\end{array}$ \\
\hline $\begin{array}{l}\text { Horizontal } \\
\text { Integration }\end{array}$ & $\begin{array}{l}\text { Elements of SD } \\
\text { are integrated } \\
\text { implicitly in all } \\
\text { competences. }\end{array}$ & $\begin{array}{l}\text { SD is included } \\
\text { in all } \\
\text { competences } \\
\text { and can be } \\
\text { seen as a larger } \\
\text { framework for } \\
\text { the competence } \\
\text { matrix. }\end{array}$ & $\begin{array}{l}\text { Implicit } \\
\text { integration of } \\
\text { SD can make it } \\
\text { into an } \\
\text { "optional" } \\
\text { element; } \\
\text { integration in the } \\
\text { curriculum is not } \\
\text { guaranteed. }\end{array}$ & $\begin{array}{l}\text { Teacher } \\
\text { training, nursing. }\end{array}$ \\
\hline $\begin{array}{l}\text { Combined } \\
\text { Integration }\end{array}$ & $\begin{array}{l}\text { Implicit } \\
\text { integration of } \\
\text { SD in all } \\
\text { competences } \\
\text { and an explicit } \\
\text { focus on one (or } \\
\text { more) } \\
\text { competence(s) } \\
\text { for SD. }\end{array}$ & $\begin{array}{l}\text { Horizontal } \\
\text { (implicit) and } \\
\text { vertical (explicit) } \\
\text { integration } \\
\text { assure a } \\
\text { framework to } \\
\text { formulate } \\
\text { competences } \\
\text { for SD. }\end{array}$ & Risk of "overkill". & $\begin{array}{l}\text { Midwifery, } \\
\text { Applied } \\
\text { Information } \\
\text { Technology. }\end{array}$ \\
\hline
\end{tabular}


These different integration strategies for competences are in line with integration strategies for sustainability in the curriculum of higher education, going from the integration of one specific course on SD (vertical integration), to an interwoven (horizontal) approach (e.g. Lozano, 2008, Wals and Jickling, 2002). Although it could be assumed that a horizontal integration in the competences would lead to a horizontal integration within the curriculum, further research is needed to find out if the integration in the competences will have the desired effect in the curriculum.

McKeown (2002) stresses that reorienting education requires teaching and learning in those domains that will guide people to pursue sustainable livelihoods, to participate in a democratic society and to live in a sustainable manner. The use of competence-based education offers a great opportunity to re-examine and reorient educational policy and systems towards sustainability, as more emphasis can be put on developing knowledge, skills, perspectives, and values related to sustainability (UNESCO, 2005). SD should be considered as a normative starting point for selecting the competences (Barth et al., 2007), but if the competences identified are not accompanied by changes in the education system and a reorientation of current curricula, "the acquisition of certain ones [competences for SD] will remain an 'accidental' side product of the educational system" (Sleurs, 2008, p. 36).

Competences for SD indicate what needs to be trained and studied. With the effective integration of competences for SD in the competence schemes of a study program, it is possible to realize a structural integration in the curriculum. At this point, it is important to think about how the competences would need to be trained, acquired, and assessed. After all, educators should guarantee that these competences are likely to be achieved by the students. Weinert (2001) states that the question is whether competences can be acquired through planned instructional programs. Students should receive a wide range of resources to internalize the knowledge, skills, values and attitudes desired, and to acquire all those competences that have been designed and selected for them. De Haan (2006), when defining the Gestaltungskompetenz (shaping competence), states that acquiring competences represents a multifaceted teaching task-teaching all subjects and learning through project work and opportunities for action on the part of students, both inside and outside the classroom.

Based on existing handbooks and articles (e.g. Ceulemans and De Prins, 2010, Scoullos and Malotidi, 2004, Steiner and Posch, 2006, Junyent and Geli, 2007, McKeown 2002, Lambrechts et al., 2009), it is possible to further define methods and techniques to teach and assess competences for SD. Analysis of these methods showed that there are three main 
characteristics of teaching and learning methods for competences for SD (Lambrechts et al., 2009):

- interactive and participative methods: Socrates method, group discussion, role play, group or personal diary, brainstorming, peer assessment, etc.;

- action oriented methods: learning through internships, solving real community problems, outdoor education, etc.;

- research methods: bibliographic research, problem analysis, value clarification, case studies, concept mapping, etc.

These methods and techniques can be used and combined to embed sustainability in the entire curriculum, thus filling the gap between theory and practice. They may even be used to assess the competences. Sluijsmans (2008) states that self-evaluation, reflection, and peer assessment can be used to make the evaluation process more sustainable. After all, assessment is too often only based on the knowledge component, which is problematic because acquiring competences can by no means be compared to pure knowledge acquisition (Sleurs, 2008). Rychen and Salganik (2003) state that competences cannot be assessed by non-current and isolated achievements. It is, as an educator, very important to guide students in their learning process, this can be done using three steps in the evaluation process (Sluijsmans, 2008):

- feed-up: give examples of what is expected during the evaluation, make evaluation criteria explicit for the students, be transparent about the assessment;

- feed-back: give sufficient feedback to the students, allowing them to learn from their evaluation as much as possible;

- feed-forward: give the students input on how to go further in their learning process.

It is clear that, regarding ESD, a lot of work has been done during the past years, covering the complete educational process: defining competences, describing integration strategies, and creating courses, modules, handbooks, and methodologies to achieve and assess these competences. However, little information is available on the actual current status of the integration of competences for SD in existing study programs. Nonetheless, this kind of information can be crucial in order to integrate new competences, or reorient existing competences towards SD. The research described in this article focuses on this lack of information, and looks at the current position of competences for SD in the study programs. 


\section{Research Questions, Scope, and Methodology}

Research questions - The integration of competences for SD can be seen as an important step in the integration of sustainability in higher education. Although competences for SD are defined and described in different models and settings, little information is available on the actual status of the integration of these competences in different study programs. Exploring this deficit, could provide answers to the following questions, thus accelerating the integration of sustainability in higher education:

1. To what extent is/are (elements of) sustainable development already integrated in the competences of different education programs?

2. How can this information be used to further integrate competences for sustainable development in the curriculum?

Scope of the research - In order to perform this research, the competences of several bachelor programs were selected, based on following criteria:

1. possibility to compare the programs-in order to achieve relevant results, bachelor programs in the following fields of management were chosen: business management, office management, and applied information technology;

2. profile of the universities: both Hogeschool-Universiteit Brussel (HUB) and Leuven University College (KHLeuven) have taken considerable steps in the integration of sustainability in their policy, research, education and operations. These efforts are rewarded with the two-star certificate of sustainability, measured by the Auditing Instrument for Sustainability in Higher Education (AISHE).

The study includes analysis of general and disciplinary competences of the management bachelor programs of HUBrussel and KHLeuven. Both universities defined general key competences, which also include SD. These general key competences are applicable for all the study programs. Each study program can slightly adapt these competences in order to align them with their own profile. Both universities also defined disciplinary competences, which are related to the specific characteristics of the study program itself. After composing this list of general and disciplinary competences per study program - i.e. the competence scheme - every teacher is responsible for selecting the competences which adequately fit their course. The head of the department is responsible for composing an overview of all competences of (all courses of) a study program: which course complies with which competence(s) and to which degree. Finally, after this selection process, the competences 
are translated into concrete and measurable goals, which are used as indicators for the evaluation of students on their exams. A teacher must be able to show that his exam is a good instrument to trace whether a student has achieved the goals and thus the competences.

Analysis of the competence schemes - A framework of analysis was developed using the key competences for SD defined by De Haan (2006), Sleurs (2008), and Roorda (2010). Although defined in different contexts and settings, there are a lot of similarities between each sets of competences, shown in Table 1. As the set of competences described by Roorda (2010) turns out to be the most comprehensive, it is used for the analysis framework. Each competence is divided into four sub-competences, giving a detailed description of what is expected of the student. Table 3 gives an overview of the competences and their subcompetences. 
Table 3. Competences for sustainable development used for the analysis (Roorda, 2010).

\begin{tabular}{|c|c|}
\hline 1. & $\begin{array}{l}\text { Responsibility: A sustainable professional takes responsibility for the own work } \\
\text { i.e.: the sustainable professional can: }\end{array}$ \\
\hline 1.1. & make a stakeholder analysis; \\
\hline 1.2. & take personal responsibility; \\
\hline 1.3. & render personal account to society; \\
\hline 1.4. & critically evaluate own actions. \\
\hline 2. & $\begin{array}{l}\text { Emotional intelligence: A sustainable professional projects him/herself on the } \\
\text { values and emotions of other people and cultures } \\
\text { i.e.: the sustainable professional can: }\end{array}$ \\
\hline 2.1. & recognize and respect values of him/herself and of other people and cultures; \\
\hline 2.2. & $\begin{array}{l}\text { recognize and respect action perspectives of him/herself and of other people and } \\
\text { cultures; }\end{array}$ \\
\hline 2.3. & listen to opinions and emotions of others; \\
\hline 2.4 . & distinguish between facts, presumptions and opinions. \\
\hline 3. & $\begin{array}{l}\text { System orientation: A sustainable professional thinks and works from a systems } \\
\text { vision } \\
\text { i.e.: the sustainable professional can: }\end{array}$ \\
\hline 3.1. & cooperate in an inter- and transdisciplinary way; \\
\hline 3.2. & think in systems, zoom in and out, i.e. alternately think analytically and holistically; \\
\hline 3.3. & think function oriented, innovative, creative, out of the box; \\
\hline 3.4 . & think chain oriented. \\
\hline 4. & $\begin{array}{l}\text { Future orientation: A sustainable professional thinks and works from a future } \\
\text { oriented perspective } \\
\text { i.e.: the sustainable professional can: }\end{array}$ \\
\hline 4.1 . & recognize and understand non-linear processes; \\
\hline 4.2. & think in varying timescales; distinguish between short term and long term approach; \\
\hline 4.3. & estimate consequence reach and consequence period of decisions; \\
\hline 4.4. & think future oriented, anticipate. \\
\hline 5. & $\begin{array}{l}\text { Personal involvement: A sustainable professional dedicates him/herself } \\
\text { personally for sustainable development } \\
\text { i.e.: the sustainable professional can: }\end{array}$ \\
\hline 5.1. & $\begin{array}{l}\text { consistently involve sustainable development in the own work as a professional } \\
\text { (sustainable attitude); }\end{array}$ \\
\hline 5.2. & keep own knowledge and expertise up-to-date, even outside of the own discipline; \\
\hline 5.3. & work with passion on dreams and ideals; \\
\hline 5.4. & apply the own conscience as the standard. \\
\hline 6. & $\begin{array}{l}\text { Action skills: A sustainable professional acts decisively and competently } \\
\text { i.e.: the sustainable professional can: }\end{array}$ \\
\hline 6.1. & weigh unweighable aspects and make choices; \\
\hline 6.2. & act when the time is ripe, not against the flow: "do without doing"; \\
\hline 6.3. & deal with uncertainties; \\
\hline 6.4 . & cisions. \\
\hline
\end{tabular}


This research uses competence schemes as the basis for analysis. The competence scheme is the best data source, as it provides information about all the competences the university wishes to train and assess in the curriculum. Three researchers analyzed the education programs separately, and afterwards, they discussed the results of their findings, and came to a consensus.

The analysis of competence schemes was done in two steps:

1. analysis of the key competences of both universities: these key competences are used in every study program, although not always to the same extent;

2. analysis of the disciplinary competences: these competences differ between the study programs.

The researchers interpreted each competence in the competence scheme, and selected those that are related to the competences for SD as described by Roorda (2010). The results of the empirical analysis were first counted as a percentage and then encoded in a four-level scale to express the integration of competences for SD within the study program: (1) little or no integration, (2) minimal integration, (3) moderate integration, (4) good integration.

Limitations of the research - The main limitations of the research can be attributed to the nature of competences. A competency scheme gives a clear and comprehensive overview of all the competences a university wishes to cover in the curriculum. Nevertheless, they do not give any information about: the actual integration of these competences; the way they are trained and assessed within the curriculum; and the important role of individual teachers in the selection, integration, and assessment of competences. In other words, the competence schemes give valuable information about the intentions of a study program, but they do not give information about the practical integration in the curriculum. Moreover, instead of measuring the adoption of competences for SD, it would be interesting to measure the learning process and learning outcomes of the students regarding SD. Although student learning on SD (or the actual output) remains the final goal of ESD - as opposed to the input (in this case the competences), these outputs still remain very hard to measure (Ceulemans et al., 2011). 


\section{Results and discussion}

Research question 1 - This research firstly sought to explore which, and to what extent, competences for SD were already integrated in the study programs. As both universities defined general key competences (not specifically related to SD), these were analyzed first. Table 4 presents the results of this analysis.

Table 4. The integration of sustainability in the key competences

\begin{tabular}{|c|c|c|c|c|c|c|c|}
\hline \multicolumn{8}{|c|}{ Competences for SD } \\
\hline \multicolumn{2}{|c|}{ Key competences } & 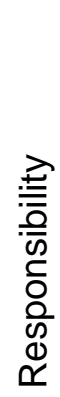 & 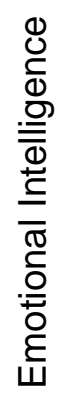 & 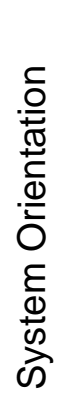 & 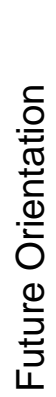 & 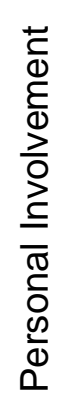 & $\begin{array}{l}\text { 里 } \\
\frac{\bar{y}}{\omega} \\
\frac{}{0} \\
\frac{0}{0}\end{array}$ \\
\hline \multirow{6}{*}{ 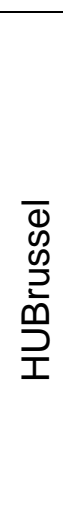 } & Practise based & 1 & 1 & 1 & 1 & 1 & 4 \\
\hline & Learning and self-reflection & 3 & 2 & 1 & 1 & 1 & 2 \\
\hline & International focus & 1 & 4 & 1 & 1 & 1 & 1 \\
\hline & Respect & 4 & 4 & 1 & 1 & 1 & 1 \\
\hline & Cooperation & 1 & 3 & 2 & 1 & 1 & 1 \\
\hline & Act sustainable & 3 & 4 & 3 & 3 & 2 & 3 \\
\hline \multirow{5}{*}{ 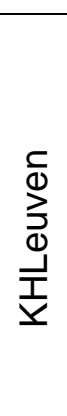 } & Learning & 3 & 3 & 2 & 1 & 2 & 2 \\
\hline & Commitment & 3 & 4 & 3 & 3 & 4 & 3 \\
\hline & Initiative & 1 & 2 & 2 & $\overline{4}$ & 1 & 4 \\
\hline & Cooperation & 1 & 4 & 3 & 1 & 1 & 2 \\
\hline & Respect & 4 & 4 & 1 & 1 & 1 & 1 \\
\hline
\end{tabular}

\begin{tabular}{|l|c|l|}
\hline Legend: & 1 & little or no integration \\
\cline { 2 - 3 } & 2 & minimal integration \\
\cline { 2 - 3 } & 3 & moderate integration \\
\cline { 2 - 3 } & 4 & good integration \\
\hline
\end{tabular}


The analysis points out that the competences for SD related to responsibility and emotional intelligence, are widely integrated within the key competences of both universities. It seems that these value-based competences are widely accepted within all education programs. The competences related to system orientation, future orientation, and action taking can be found within the key competences, but this relationship is not very pronounced. Competences related to personal commitment are virtually absent. Overall, most of the competences for SD are covered in a certain way within the key competences, thus providing a lot of opportunities to further integrate sustainability within the curriculum.

The individual competence schemes, containing the disciplinary competences for each bachelor program, were analyzed in the same way. The bachelor programs in business management integrate competences for SD and corporate social responsibility (CSR) as one focused, explicit competence. Furthermore, elements of sustainability are also present in the competences - for example linked with business ethics and responsibility. The competence schemes of the bachelor programs in office management contain elements of SD in an implicit and fragmented way. Finally, the competence scheme of the Bachelor program in Applied Information Technology of Leuven University College contains several explicit competences for SD.

All competence schemes contain elements of SD in a fragmented way. This means that there are few competences which focus on the concept of SD, but a lot of competences include partial elements of SD - such as 'cooperating in an interdisciplinary way'. Competences for SD are often more closely linked with ethical and moral attitudes, and less so with system orientation, future orientation, and action taking. Elements of sustainability are frequently implicitly present in the competence schemes. This implies that competences for SD are passed onto the students in an "unconscious" or "unofficial" way, because they are not explicitly positioned within the context of SD.

Table 5 gives an overview of the results of the analysis of the individual study programs. The analysis points out that a lot of emphasis is put on competences related to responsibility and emotional intelligence, especially in the bachelor programs of business management. On the other hand, competences related to future orientation and personal commitment are virtually absent. Action-oriented competences are also underrepresented. Some competences related to system orientation are present in the competence schemes, especially those stressing interdisciplinary cooperation, but still the competences for system orientation are too fragmented. 
Table 5. Analysis of the individual competence matrices

\begin{tabular}{|c|c|c|c|c|c|c|}
\hline $\begin{array}{l}\text { Competence Matrix of } \\
\text { Individual Bachelor Programs }\end{array}$ & 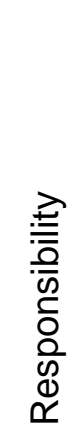 & 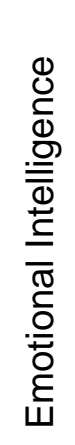 & 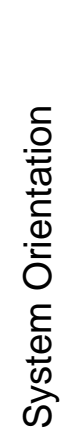 & 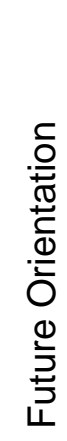 & 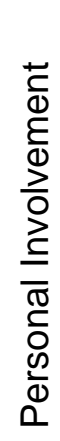 & 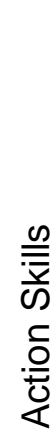 \\
\hline \multicolumn{7}{|l|}{ Bachelor in Business Management } \\
\hline KHL - Accounting - Fiscal studies & 3 & 2 & 2 & 1 & 2 & 3 \\
\hline $\mathrm{KHL}$ - Finance \& Insurance & 3 & 3 & 2 & 1 & 2 & 3 \\
\hline KHL - Marketing & 3 & 3 & 2 & 1 & 2 & 2 \\
\hline HUB - Business Management & 2 & 3 & 1 & 1 & 1 & 1 \\
\hline \multicolumn{7}{|l|}{ Bachelor in Office Management } \\
\hline KHL -Office Management & 2 & 2 & 2 & 1 & 1 & 1 \\
\hline HUB - Office Management & 2 & 3 & 1 & 1 & 1 & 1 \\
\hline \multicolumn{7}{|l|}{ Bachelor in Applied Information Technology } \\
\hline KHL - Applied Information Technology & 2 & 2 & 2 & 2 & 1 & 2 \\
\hline HUB - Applied Information Technology & 2 & 3 & 1 & 1 & 1 & 1 \\
\hline
\end{tabular}

\begin{tabular}{|l|c|l|}
\hline Legend: & 1 & little or no integration \\
\cline { 2 - 3 } & 2 & minimal integration \\
\cline { 2 - 3 } & 3 & moderate integration \\
\cline { 2 - 3 } & 4 & good integration \\
\hline
\end{tabular}

The analysis showed that competences for SD are already present in different ways: implicitly and fragmented, or explicitly and focused. An implicit and fragmented integration means that one or more existing competences contribute to the competences for SD, although not mentioning them explicitly. A fragmented integration does the opposite: it 
interweaves the competences for SD in other competences. An explicit and focused competence, on the other hand, focuses strongly on one or more elements of sustainability, e.g. transdisciplinary approach, respecting other people's values and perspectives. Integrating competences for SD in a focused way means that these competences are very clear within the matrix. These findings are in line with research findings concerning integration strategies in the fields of teacher training, health care and technology (Lambrechts et al. 2010).

Research question 2 - The second research question looked at the further integration of competences for SD, based on the results of the analysis; the results give some concrete starting points to emphasize and further integrate competences for SD. It is clear that elements of system orientation and future orientation have to be stressed, as these competences are lacking in the competence schemes. On the other hand, competences related to responsibility and emotional intelligence frequently appear in the matrices. Furthermore, each bachelor program can now decide which integration strategy to apply whether to integrate SD implicitly, explicitly, focused, or fragmented; horizontally, vertically, or combined. It is important to highlight that there is no "good" or "bad" strategy, and that implications for the curriculum shall differ for each program.

Another result of the analysis is that much emphasis is put on the (general) key competences for SD, but that a translation towards disciplinary competences for SD is still missing. This illustrates that competences for SD are only defined and integrated in general terms. Although this approach is already valuable, it is not enough to thoroughly reorient the study program towards SD and prepare students for their professional and personal roles in achieving a sustainable society. In order to achieve sustainability in higher education, this important deficit has to be tackled.

Most competences for SD are strongly linked with ethical and moral elements. Other competences, related to future orientation, system orientation, personal involvement and action taking, are virtually absent. It is interesting to see that these results within two Belgian universities are in line with the findings of a similar research in Catalan universities (Cortés et al., 2010) and a comparable analysis for bachelor programs in social work in Flanders, Belgium (Peeters and Van Poeck, 2010). The remarkable absence of some key competences for SD requires a reorientation of existing, or integration of new competences.

Finally, the research also points out that the combination of the two educational innovations i.e. competences and ESD - does not necessarily present a contradiction, viewing the fact 
that the competences for SD are mainly represented in the curriculum via ethically and morally related - or value driven - competences.

\section{Conclusion}

Many higher education institutions have integrated SD in competences and curriculum. In the two universities described in this article, SD is a main value for policy, education, research, outreach, and operations, therefore, many of their study programs have integrated sustainability. The competences within these universities were analyzed in three professional bachelor programs: business management, office management, and applied information technology. In order to find out the present status of SD integration, the study programs were analyzed on two levels. Firstly, the general key competences of each university were analyzed; secondly, the disciplinary competences for each study program were analyzed. A framework for analysis was developed, based on the competences for SD as described by Roorda (2010), who defined six groups, related to: (1) responsibility, (2) emotional intelligence, (3) system orientation, (4) future orientation, (5) personal involvement and (6) action skills. The analysis pointed out that, despite valuable efforts, the integration of SD in competences shows some deficits: it is too implicit, too fragmented, and incomplete.

Regarding the general key competences, results show that competences related to responsibility and emotional intelligence are widely integrated in both universities. It seems that these value-based competences are widely accepted within all education programs. Competences related to system orientation, future orientation, and action skills can be found only implicitly and incompletely within the key competences. Moreover, competences related to personal involvement are virtually absent. Overall, most of the competences for SD are covered in a certain way within the key competences, ranging from very weak and incomplete, to very strong and explicit, thus providing a lot of opportunities to further integrate sustainability within the competences and curriculum.

The disciplinary competences for each bachelor program were analysed, showing that few competences focus on the concept of SD, but many competences include partial elements of SD. Competences for SD are more often linked with ethical and moral attitudes, and less frequently with system orientation, future orientation, and action skills. Elements of SD are frequently implicitly present in the competence matrices. This implies that competences for SD are passed on to the students in an "unconscious" or "unofficial" way, because they are not explicitly positioned within the context of SD. Another finding of the research is that much 
emphasis is put on the (general) key competences for SD, but that a translation towards disciplinary competences for SD is still missing.

In order to truly reorient higher education towards sustainability, these deficits need to be tackled. As pointed out by UNESCO (2005), competence-based education offers great opportunities to re-examine and reorient educational policy and systems towards sustainability. The further integration of competences for SD, especially paying attention to those competences linked with future orientation, system orientation, personal involvement, and action skills, should substantially contribute to a truly integrative approach towards ESD. It can help create much needed, new mental models, as described by Tilbury and Mulà (2011), who point out that these new mental models are required in order to transform the way we interpret and respond to our existing world. Integrating these competences could really speed up the integration process of sustainability in higher education, but as Lozano (2010) pointed out, this process is still too slow.

As a final conclusion, the authors state that more research is needed on the link between the integration of SD in competences, and the actual integration within the curriculum. It is clear that the definition of competences is only one element in the integration of sustainable higher education, and it has to be seen as a part of a broader process, combined with other teaching methods that assure the acquisition of the competences, and the important role of individual teachers in this process. Moreover, competences for SD will evolve throughout the years, demanding a constant review and revision.

\section{Acknowledgements}

The authors would like to thank all cooperating education staff members of Katholieke Hogeschool Leuven and Hogeschool-Universiteit Brussel for providing data, useful information and feedback during the research project. 


\section{References}

Baethge, M., Achtenhagen, F., Arends, L., Babic, E., Baethge-Kinsky, V., Weber, S., 2006. PISA-VET. A Feasibility-Study. Franz Steiner Verlag, Stuttgart.

Barnes, P., Jerman, P., 2002. Developing an environmental management system for a multiple-university consortium. Journal of Cleaner Production, 10, 33-39.

Barth, M., Godemann, J., Rieckmann, M., Stoltenberg, U., 2007. Developing key competencies for sustainable development in higher education. International Journal of Sustainability in Higher Education, 8(4), 416-430.

Behrens, B., Müller-Christ, G., 2005. Innovative Sustainability Monitoring and Reporting for Universities. Conference on the International Launch in Higher Education: Conference Proceedings: Committing Universities to Sustainable Development. Graz, Austria, April 2005, 239-248.

Calder, W., Clugston, R., 2003. Progress Toward Sustainability in Higher Education. Washington: Environmental Law Reporter.

Ceulemans, K., De Prins, M., 2010. Teacher's manual and method for SD integration in curricula. Journal of Cleaner Production, 18, 645-651.

Ceulemans, K., De Prins, M., Cappuyns, V., De Coninck, W., 2011. Integration of sustainable development in higher education's curricula of applied economics: large scale assessments, integration strategies and barriers. Journal of Management and Organization, 17: 621-640.

Cheetham, G. and Chivers, G., 1996. Towards a holistic model of professional competence. Journal of European Industrial Training, 20 (5), 20 - 30.

Corcoran, P.B., Wals, A., 2004. Higher education and the challenge of sustainability. Problematics, Promise and Practice. Kluwer Academic Publishers, Dordrecht/Boston/Londen.

Cortés, A.C., Segalas, J., Cebrian, G., Junyent, M., Tilló, T., Marquilles, P., Montserrat, M., 2010. Sustainability competences in Catalan university degrees. Proceedings of the 6th Conference 'Environmental Management for Sustainable Universities (EMSU)', Delft, The Netherlands, 25-29 oktober 2010.

Cortese, A.D., 2003. The critical role of higher education in creating a sustainable future, Planning for Higher Education, 31 (3), 15-22.

De Haan, G., 2006. The BLK '21' programme in Germany: A 'Gestaltungskompetenz'-based model for Education for Sustainable Development. Environmental Education Research, 12: 19-32.

Fien, J., 2002. Advancing sustainability in higher education: issues and opportunities for research. Higher Education Policy 15, 143-152.

Hermans, I., 2007. Competentiegericht onderwijs als strategische doelstelling. Visie en ervaringen van de KHLeuven (Competence based education as a strategic objective. Vision and experience of Leuven University College). Ethische Perspectieven (Ethical Perspectives), 17(4), 372-390. 
Junyent, M., Geli, A.M., 2007. The ACES Network: curriculum greening of Higher Education. Good Practices in Education for Sustainable Development: Teacher Education Institutions. UNESCO-Education for Sustainable Development in Action. Good Practices N $1-2007$.

Lambrechts, W., Mulà, I., Van den Haute, H., 2010. The integration of sustainability in competence based higher education. Using competences as a starting point to achieve sustainable higher education. Proceedings of the 6th Conference 'Environmental Management for Sustainable Universities (EMSU)', Delft, The Netherlands, 25-29 oktober 2010.

Lambrechts, W., Van den Haute, H., Vanhoren, I., 2009. Duurzaam hoger onderwijs. Appel voor verantwoord onderrichten, onderzoeken en ondernemen (Sustainable higher education. Appeal for responsible education, research and operations). Leuven, LannooCampus.

Lidgren, A., Rodhe, H., Huisingh, D., 2005. A systemic approach to incorporate sustainability into university courses and curricula. Journal of Cleaner Production, 14, 797-809.

Lozano, R and Peattie, K., 2011. Assessing Cardiff University's curricula contribution to SD using the STAUNCHC System, Journal of Education for Sustainable Development, 5.

Lozano, R., 2010. Diffusion of sustainable development in universities' curricula: an empirical example from Cardiff University. Journal of Cleaner Production, 18, 637-644.

Lozano, R., 2008. Diffusion of sustainable development in universities' curricula: an empirical example from Cardiff University. Fifth international EMSU conference. Barcelona, Spain: Environmental Management for Sustainable Universities.

Lozano, R., 2006a. A tool for a Graphical Assessment of Sustainability in Universities (GASU). Journal of Cleaner Production 14, 963-972.

Lozano, R., 2006b. Incorporation and institutionalization of SD into universities: breaking through barriers to change. Journal of Cleaner Production, 14, 787-796.

Lozano, R., Lukman, R., Lozano, F.J., Huisingh, D., Zilahy, G., 2010. Jumping sustainability meme: SD transfer from society to universities. Proceedings of the 6th Conference 'Environmental Management for Sustainable Universities (EMSU)', Delft, The Netherlands, 25-29 oktober 2010.

McKeown, R., 2002. Education for Sustainable Development Toolkit. Retrieved on 19 August 2010, from http://www.esdtoolkit.org.

Muijen, H., 2004. Integrating value education and sustainable development into a Dutch university curriculum. International Journal of Sustainability in Higher Education, Vol. 5 Iss: 1, pp. $21-32$.

Müller, J., 2005. Environmental management in German institutions of higher education: lessons learnt and steps toward sustainable management. Conference 'Sustainable management of higher education institutions', Lüneburg (23-24 juni 2005).

Peeters, J., Van Poeck, K., 2010. Educatie voor duurzame ontwikkeling: een vernieuwde visie op leren en onderwijzen (Education for sustainable development: a new vision on learning and teaching). In: Peeters, J. (ed.), Een veerkrachtige samenleving. Sociaal werk en duurzame ontwikkeling (A resilient society. Social work and sustainable development). Uitgeverij EPO, Berchem, 329-339. 
Roorda, N., 2010. Sailing on the winds of change. The Odyssey to Sustainability of the Universities of Applied Sciences in the Netherlands. PhD thesis, Maastricht University.

Roorda, N., 2002. Assessment and Policy Development of Sustainability in Higher Education with AISHE. In Filho, W.L (ed.). Teaching Sustainability at Universities: towards curriculum greening, Environmental education, communication and sustainability. Frankfurt: Peter Lang.

Rychen, D.S., 2002. Key Competencies for the Knowledge Society. A contribution from the OECD Project Definition and Selection of Competencies (DeSeCo). Presented at Conference: Education-Lifelong Learning and the Knowledge Economy. October, 10-11, Stuttgart, Germany.

Rychen, D.S., Salganik, L.K., 2003. Key Competencies for a Successful Life and a WellFunctioning Society. Germany: Hogrefe \& Huber.

Savely, S.M., Carson, A.I., Declos, G.L., 2007. An environmental management system implementation model for U.S. colleges and universities. Journal of Cleaner Production 15 (2007) 660-670.

Scoullos, M., Malotidi, V., 2004. Handbook on Methods used in Environmental Education for Sustainable Development Athens: MIO-ECSDE.

Sleurs, W. (ed.), 2008. Competences for ESD (Education for Sustainable Development) teachers. A framework to integrate ESD in the curriculum of teacher training institutes, Brussels.

Shriberg, M., 2002a. Towards sustainable management: the University of Michigan Housing Division's approach. Journal of Cleaner Production 10, 41-45.

Shriberg, M., 2002b. Institutional assessment tools for sustainability in higher education. International Journal of Sustainability in Higher Education, vol. 3 No. 3, 254-270.

Sluijsmans, D., 2008. Duurzaam beoordelen en vraaggestuurd leren. Betrokken bij beoordelen. Intreerede. (Sustainable assessment and demand-driven learning. Involved in assessment. Inaugural lecture). Faculty of Education, Hogeschool van Arnhem en Nijmegen, The Netherlands (6 juni 2008).

Steiner, G., Posch, A., 2006. Higher education for sustainability by means of transdisciplinary case studies: an innovative approach for solving complex, realworld problems. Journal of Cleaner Production 14, 877-890.

Sterling, S., Scott, W., 2008. Higher education and ESD in England: A critical commentary on recent initiatives. Environmental Education Research, vol 14, no 4, pp386-398.

Sterling, S., 2004. Higher education, sustainability, and the role of systemic learning. In: Corcoran, P.B. en Wals, A. Higher education and the challenge of sustainability. Problematics, Promise and Practice. Kluwer Academic Publishers, Dordrecht/Boston/Londen, 47-70.

Tilbury, D., Mulà, I., 2011. Review of Education for Sustainable Development (ESD) Strategies from a Cultural Diversity and Intercultural Dialogue Perspective. Paris, UNESCO.

UNESCO, 2005. United Nations Decade of Education for Sustainable Development (20042015): Draft International Implementation Scheme. Paris: UNESCO. 
UNESCO, 2009. Policy Dialogue 1: ESD and Development Policy: Education and the Search for a Sustainable Future. Paris: UNESCO.

Velázquez, L., Munguia, N., Platt, A., Taddei, J., 2006. Sustainable university: what can be matter?. Journal of Cleaner Production, 14, 810-819.

Viebahn, P., 2002. An environmental management model for universities: from environmental guidelines to staff involvement - Papers from 1999 Environmental Management Conference on Sustainable Education. Journal of Cleaner Production 10 (2002) pp. 3-12.

Wals, A.E.J., 2010. Mirroring, Gestaltswitching and transformative social learning: Stepping stones for developing sustainable competence. International Journal of Sustainability in Higher Education, 11 (4): 380-390.

Wals, A., Jickling, B., 2002 "Sustainability" in higher education: from doublethink and newspeak to critical thinking and meaningful learning. Higher Education Policy 15, 121-131.

Weinert, F., 2001. Concept of Competence: A Conceptual Clarification. In Rychen, D.S. and Salganik, L.H. (eds.). Defining and Selecting Key Competences (pp. 45-65). Germany: Hogrefe \& Huber.

Wright, T., 2004. The evolution of sustainability declarations in higher education. In: Corcoran, P.B. en Wals, A. Higher education and the challenge of sustainability. Problematics, Promise and Practice. Kluwer Academic Publishers, Dordrecht/Boston/Londen, 7-20. 